\title{
Tanggung Jawab Notaris Menggunakan Layanan Ditjen Ahu Online Dalam Hal Pendaftaran Akta Dan Pengesahan Badan Hukum
}

\section{Gede Agus Yudi Suryawan'1, Dewa Nyoman Rai Asmara Putra²}

${ }^{1}$ Program Studi Magister (S2) Kenotariatan, Fakultas Hukum Universitas Udayana, BaliIndonesia, Email: gusyudijurnal69@gmail.com

${ }^{2}$ Fakultas Hukum Universitas Udayana, Email: dewar2566@gmail.com

\begin{tabular}{l}
\hline Info Artikel \\
\hline Masuk:5 September 2020 \\
Diterima:18 November 2020 \\
Terbit: 15 Desember 2020 \\
Keywords: \\
Legal protection; Traditional \\
Knowledge; Copyrights \\
\\
\\
Corresponding Author: \\
I Gede Agus Yudi \\
Suryawan, E-mail: \\
gusyudijurnal69@gmail.com \\
DOI: \\
10.24843/AC.2020.v05.i03.p05 \\
Cerlindungan hukum; \\
cipta \\
Cata kunci:
\end{tabular}

\begin{abstract}
In accordance with the Decree of the Minister of Justice and Human Rights Number M-05 HT.01.01 of 2002 concerning the Enforcement of the Legal Entity Administration System at the Directorate General of General Legal Administration of the Ministry of Justice and Human Rights of the Republic of Indonesia, determines that all legal entity settlements include the ratification of the deed of establishment PT, application for approval and submission of deed reports, amendments to articles of association, fiduciary registration, will registration, are carried out with the online Legal Entity Administration System. So the notary has the authority to register all these legal acts online. The purpose of this research is to find out the role of the Notary in registering deeds and legalization of legal entities through the Directorate General of AHU Online services and to find out the responsibilities of the Notary if there are problems in registering deeds and legal entity approval through the services of the Directorate General of AHU Online. This study uses a normative juridical research method using a statutory approach and a conceptual approach. The results of the research, namely, the role of the notary in registering deeds and ratifying legal entities is entering deed data, checking all deed data to avoid data entry errors and the notary has the responsibility if there is an error from the notary's office, the notary will make corrections at a cost of Notary, however in this regard there is still cooperation from the applicant regarding the required data.
\end{abstract}

\begin{tabular}{l}
\hline Abstrak \\
\hline Sesuai dengan Keputusan Menteri Kehakiman dan Hak Asasi \\
Manusia Nomor M-05 HT.01.01 Tahun 2002 tentang \\
Pemberlakuan Sistem Administrasi Badan Hukum di Direktorat \\
Jenderal Administrasi Hukum Umum Departemen Kehakiman \\
dan Hak Asasi Manusia Republik Indonesia, menentukan bahwa \\
segala penyelesaian badan hukum yang meliputi pengesahan \\
akta pendirian PT, permohonanpersetujuan sertapenyampaian \\
laporan akta, perubahan anggaran dasar, pendaftaran fidusia, \\
pendaftaran wasiat, dilaksanakan dengan Sistem Administrasi \\
Badan Hukum secara online. Makanotaris memiliki wewenang \\
dalam mendaftarkan secara online segala perbuatan hukum \\
tersebut. Tujuanpenelitian ini untukmengatahuiperan Notaris \\
dalam melakukan pendaftaran akta dan pengesahan badan
\end{tabular}




\begin{abstract}
hukum melalui layanan Ditjen AHU Online dan mengetahui tanggung jawab Notaris jika terdapat masalah dalam dalam melakukan pendaftaran akta dan pengesahan badan hukum melalui layanan Ditjen AHU Online. Penelitian ini menggunakan metode peneltian yuridis normatif menggunakan pendekatan perundang-undangan, dan pendekatan konseptual. Hasil dari penelitian yakni, peran Notaris dalam pendaftaran akta dan pengesahan badan hukum adalah memasukkan data akta, melakukan pengecekan terhadap semua data akta untuk menghindari kesalahan pemasukan data dan Notaris memiliki tanggung jawab jika terjadi kesalahan dari pihak kantor Notaris maka Notaris akan melakukan perbaikan dengan biaya dari Notaris, namun berkenaan dengan hal tersebut tetap adanya kerjasama dari pihak pemohon mengenai data-data yang diperlukan.
\end{abstract}

\title{
I. Pendahuluan
}

Notaris diberikan jabatan oleh Negara untuk memberikan kepastian hukum kepada masyarakat, dalam kewenangannya menjalankan jabatannya tersebut Notaris bertugas untuk membuat akta otentik, akta otentik juga bersifat sebagai alat bukti yang sah tentang semua perbuatan, keterangan para pihak yang dilakukan. Berbagai macam perbuatan hukum yang bisa dilakukan dengan akta otentik adalah seperti : jual beli, pendirian PT, wasiat, fidusia, dan segala macam perjanjian lainnya. ${ }^{1}$

Akta yang dibuat oleh Notaris adalah berkaitan dengan tindakan, perjanjian, dan keputusan yang diwajibkan oleh aturan UU atau para pemohon agar dapat dinyatakan di dalam surat yang sifatnya otentik, surat tersebut dinamakan akta otentik yang dapat dijadikan sebagai alat bukti atas perbuatan hukum yang dilakukan. Akta otentik di dalamnya dapat menjamin kepastian tanggal, dan Notaris berkewajiban untuk menyimpan akta, memberikan salinan, memberikan grosse atau salinan sah, kutipan dan terhadap semua itu dan pembuatannya tidak dilimpahkan kepada pejabat lain atau yang diperintahkan khusus oleh UU.

Berbagai macam perbuatan hukum yang dimasukkan ke dalam akta otentik diantaranya adalah memerlukan persetujuan menteri hukum dan hak asasi manusia Republik Indonesia, dalam hal tersebut persetujuan dari menteri hukum dan hak asasi manusia Republik Indonesia tersebut diberikan dalam bentuk Surat Keputusan. Surat Keputusan tersebut dapat menerangkan tentang perbuatan hukum apa yang telah diperbuat oleh para pihak dan oleh Notaris dimasukkan ke dalam akta otentik.

Notaris dalam kewajibannya membuat akta otentik, juga mempunyai kewenangan dalam hal menginput data akta agar memperoleh persetujuan menteri hukum dan hak asasi manusia Republik Indonesia melalui Direktorat Jenderal Administrasi Hukum Umum atau yang disingkat Dirjen AHU. Pengertian Notaris menurut UU No. 3 Th. 2004 tentang Jabatan Notaris dan dirubah menjadi UU No. 2 Th. 2014, selanjutnya

${ }^{1}$ Budiono, Herlien. (2012). Arah Pengaturan Undang-Undang Nomor 40 Tahun 2007 tentang Perseroan Terbatas dalam Menghadapi Era Global. Jurnal Rechts Vinding: Media Pembinaan Hukum Nasional, 1(2), 187-198. h. 187 
disebut UUJNP, dalam Pasal 1 angka 1 adalah merupakan pejabat umum yang berwenang membuat akta otentik dan mempunyai kewenangan lainnya sebagaimana yang dimaksud dalam UU ini atau atas dasar UU lainnya.

Kewenangan Notaris yang dimaksud adalah telah dijelaskan dalam Pasal 15 ayat (1) UUJNP adalah:

Membuat akta otentik yang didalamnya menerangkan semua perbuatan, perjanjian serta penetapan yang diharuskan oleh UU dan dikehendaki oleh pihak yang berkepentingan yang ingin dinyatakan ke dalam akta otentik, dan dasar akta tersebut telah menjamin kepastian tanggal pembuatan akta, menyimpan akta, memberikan grosse, salinan dan kutipan akta, dan sepanjang pembuatan akta tersebut tidak dilimpahkan kepada pejabat lain atau orang lain yang ditetapkan oleh UU.

Kaitannya dalam memberikan kepastian hukum dan juga hak serta kewajiban seseorang membutuhkan peran Notaris unntuk dapat memberikan kepastian hukum dan perlindungan hukum sangatlah penting didalam melakukan perbuatan hukum pada zaman yang sangat berkembang ini. Dalam hal ini peran Notaris bersifat sebagai pencegahan terhadap terjadinya masalah hukum, dan berfungsi sebagai alat bukti yang paling sempurna didepan pengadilan ketika terjadi sengketa. ${ }^{2}$ Dalam menjalankan tugasnya, Notaris bertumpu pada UUJN dan UUJNP yang menyatakan bahwa tugas utama Notaris adalah membuat akta otentik, otentik dalam Pasal 1870 KUHPerdata adalah akta yang memberikan perjanjian yang absolut kepada pihak yang berkepentingan, dapat dikatakan bahwa jabatan Notaris sangat penting di dalam kewenangannya yang diberikan oleh UU untuk membuat alat bukti yang kuat.

Menciptakan kepastian hukum di masyarakat adalah tugas seorang Notaris dengan membuat akta yang memiliki sifat otentik karena dapat dijadikan sebagai pembuktian yang kuat dan penuh apabila dikemudian hari terjadi masalah yang kaitannya dengan akta tersebut. Meningkatnya hubungan bisnis di berbagai bidang usaha baik dari skala lokal maupun internasional menyebabkan kebutuhan akan akta otentik semakin meningkat, tidak hanya yang berbau bisnis, perbuatan hukum dalam hal fidusia, dan pernyataan wasiat oleh orang semasa hidupnya juga memerlukan kepastian hukum.

Berbagai macam perbuatan hukum yang telah dituangkan kedalam akta otentik tersebut berdasarkan keputusan Menteri Hukum dan Hak Asasi Manusia Republik Indonesia haruslah mendapatkan persetujuan menteri yang menyatakan bahwa segala perbuatan hukumnya telah memperoleh persetujuan. Dalam hal memperoleh persetujuan tersebut, Notaris atas dasar Keputusan Menteri Kehakiman dan Hak Asasi Manusia Nomor M-05 HT.01.01 Tahun 2002 tentang Pemberlakuan Sistem Administrasi Badan Hukum di Direktorat Jenderal Administrasi Hukum Umum Departemen Kehakiman dan Hak Asasi Manusi Republik Indonesia, yang menyatakan bahwa segala penyelesaian badan hukum yang meliputi badan hukum yang meliputi pengesahan akta pendirian PT, permohonan persetujuan serta penyampaian laporan akta, perubahan anggaran dasar, pendaftaran fidusia, pendaftaran wasiat,

2Sjaifurahman \& Habi Adjie. 2011, Aspek Pertanggungjawaban Notaris dalam Pembuatan Akta, CV. Mandar Maju, Bandung, hal. 7 
dilaksanakan dengan Sistem Administrasi Badan Hukum (SISMINBAKUM) secara online.

Telah terjadi perubahan penginputan data akta dari manual ke sistem online dengan harapan bahwa dalam pendaftaran dan pengesahan dapat berjalan lebih efisien dan lebih efektif, dalam pelaksanaan menggunakan layanan Ditjen AHU Online tersebut tetap membutuhkan peran Notaris yang membuat akta. Tidak menutup kemungkinan bahwa akan terjadi masalah yang dapat menjadi kendala khususnya terkait dengan peran dari Notaris. Kendala yang dapat terjadi antara lain, kurangnya pemahaman dan pengetahuan tentang layanan Ditjen AHU, kurangnya keterampilan dalam mengoperasikan komputer dan internet sebagai sarana yang paling utama dalam layanan Ditjen AHU secara online. ${ }^{3}$ Hal-hal seperti demikian sangat memungkinkan terjadinya kesalahan pemasukan data atau keabsahan data bahkan dapat juga terjadi penyalahgunaan data. Apabila hal ini terjadi maka akibat yang timbul di dalamnya adalah menjadi tanggung jawab dari Notaris itu sendiri.

Pada penelitian ini adapun pemasalahan yang diangkat mengenai bagaimana peran Notaris dalam melakukan pendaftaran akta dan pengesahan badan hukum melalui layanan ditjen AHU online dan bagaimana tanggung jawab Notaris jika terdapat masalah dalam melakukan pendaftaran akta dan pengesahan badan hukum melalui layanan ditjen AHU online.

Tujuan dari penelitian ini dilakukan untuk menganalisis dan memahami peran Notaris dalam melakukan pendaftaran akta dan pengesahan badan hukum melalui layanan ditjen AHU online dan tanggung jawab Notaris jika terdapat masalah dalam melakukan pendaftaran akta dan pengesahan badan hukum melalui layanan ditjen AHU online.

Penelitian terdahulu yang berkaitan dengan penelitian ini, telah dilakukan oleh Evi Veronika pada tahun 2019, adapun kesimpulan pada penelitian yakni pengesahan dan pendaftaran perseroan terbatas, yayasan dan jaminan fidusia melalui mekanisme sistem AHU online dimulai dengan dilakukannya pemesanan nama, pembuatan akta pendirian hingga melakukan pengesahan dan pendaftaran. Akibat hukum apabila gagal dilakukan pengesahan karena gangguan sistem AHU online yang melewati batas jangka waktu yang ditentukan oleh undang-undang, menjadikan badan hukum tersebut tidak mempunyai status badan hukum dan akta jaminan fidusia aktanya tidak memiliki kekuatan eksekutorial. Notaris bertanggungjawab apabila terjadi kegagalan dalam pengesahan dan pendaftaran perseroan terbatas, yayasan dan pendaftaran akta jaminan fidusia karena gangguan pada sistem AHU online. Adapun penyelesaian dapat menghubungi pihak AHU online. ${ }^{4}$

${ }^{3}$ Erlina Permatasari \& Lathifah Hanim, PERAN DAN TANGGUNG JAWAB NOTARIS TERHADAP PELAKSANAAN PENDAFTARAN BADANHUKUM PERSEROAN TERBATAS MELALUI SISTEM ONLINE, Jurnal Akta, Vol. 4 No. 3 September 2017

4Perangin-Angin, E. V. (2019). Analisis Yuridis Atas Gagalnya Pengesahan, Pendaftaran Perseroan Terbatas, Yayasan dan Jaminan Fidusia Melalui Sistem Administrasi Hukum Umum (AHU) Online. 
Berdasarkan latar belakang diatas maka penulis tertarik untuk melakukan penelitian dengan judul "TANGGUNG JAWAB NOTARIS MENGGUNAKAN LAYANAN DITJEN AHU ONLINE DALAM HAL PENDAFTARAN AKTA DAN PENGESAHAN BADAN HUKUM"

\section{Metode Penelitian}

Pada penelitian ini menggunakan metode penelitian hukum normatif. Penelitian hukum normatif merupakan teknik dalam menelaah peraturan perundang-undangan yang melihat hierarki perundang-undangan secara vertikal dan horizontal. ${ }^{5}$ Pendekatan yang digunakan untuk menjawab permasalahan dalam penelitian ini yaitu, Pendekatan Undang-Undang (statutes approach), Pendekatan konseptual (conceptual approach) dan Pendekatan analisis (analytical approach). Penelitian ini menggunakan bahan hukum primer yaitu bahan hukum yang bersifat mengikat yang mencakup peraturan perundang-undangan terkait dengan permasalahan, bahan hukum primer yakni Undang-Undang Negara RI, Undang-Undang No. 2 Th. 2014 tentang perubahan Undang-Undang Negara RI, Undang-Undang No. 30 Th. 2004 tentang Jabatan Notaris dan Undang-Undang Negara RI, Undang-Undang No. 40 Th. 2007 tentang Perseroan Terbatas. Untuk bahan hukum sekunder, yang berupa bahanbahan hukum yang menjelaskan lebih lanjut dan memberi keterangan mengenai bahan hukum primer. ${ }^{6}$ Literatur, berupa buku dan jurnal hukum dipergunakan sebagai bahan hukum sekunder. Artikel-artikel dari internet dipakai sebagai bahan hukum tersier. Teknik pengumpulan bahan hukum yang membantu menyelesaikan permasalahan ini ialah teknik sistematisasi bahan hukum primer serta teknik bola salju pada bahan hukum, sekunder serta bahan hukum lainnya. Metode analisis bahan hukum penulisan ini ialah tenik deskriptif yang menjelaskan mengenai peristiwa atau kondisi hukum. ${ }^{7}$

\section{Hasil Dan Pembahasan}

\subsection{Peran Notaris dalam melakukan pendaftaran akta dan pengesahan badan hukum melalui layanan Ditjen AHU Online}

Berdasarkan ketentuan dalam Undang-Undang Nomor 30 Tahun 2004 Tentang Jabatan Notaris (selanjutnya disebut UUJN) sebagaimana dirubah dengan Undang-Undang Nomor 2 Tahun 2014 Tentang Perubahan atas Undang-Undang Nomor 30 Tahun 2004 Tentang Jabatan Notaris (selanjutnya disebut UUJN-P) sebagai peraturan yang mengakomodir jabatan notaris menyatakan Pasal 1 angka 1 UUJN-P notaris adalah "Pejabat umum yang berwenang untuk membuat akta autentik dan memiliki

5Pratama,I., \& Priyanto, I. (2020). Kepastian Hukum Jumlah Modal Dasar Pendirian Perseroan Terbatas Setelah Berlakunya PP Perubahan Modal Dasar Perseroan Terbatas. Acta Comitas : Jurnal Hukum Kenotariatan, 5(2), 340-350.

${ }^{6}$ Anggraeni, S., \& Marwanto, M. (2020). Kewenangan dan Tanggung Jawab Hukum Pejabat Pembuat Akta Tanah Dalam Pelaksanaan Pendaftaran Hak Tanggungan Secara Elektronik. Acta Comitas : Jurnal Hukum Kenotariatan, 5(2), 261-273.

7I Made Pasek Diantha. (2017). Metodelogi Penelitian Hukum Normatif dalam Justifikasi Teori Hukum. Jakarta: Prenada Media Group, p. 153. 
kewenangan lainnya sebagaimana dimaksud dalam undangundang ini atau berdasarkan undang-undang lainnya".

Kewenangan Notaris dalam membuat akta otentik, juga berwenang dalam pendaftaran akta tersebut dalam hukumnya mendapatkan persetujuan Menteri Hukum dan Hak Asasi Manusia RI yang persetujuannya dalam bentuk Surat Keputusan. Macam-macam akta yang membutuhkan persetujuan Menteri Hukum dan Hak Asasi Manusia RI adalah:

1. Akta pendirian PT;

2. Akta perubahan anggaran dasar PT;

3. Akta Fidusia;

4. Akta Wasiat;

Notaris memiliki tanggung jawab terhadap pendirian Perseroan Terbatas dari adanya ketentuan mengenai pendirian Perseroan Terbatas merupakan suatu perjanjian yang dibuat dan dituangkan dalam suatu akta notariil. Pada Pasal 7 ayat (1) UUPT menentukan bahwa perseroan terdiri oleh 2 (dua) orang atau lebih dengan akta notaris yang dibuat dalam bahasa Indonesia. Sesuai dengan ketentuan dalam Pasal 1868 KUHPerdata menentukan sebagai berikut :

"Akta otentik adalah akta yang dibuat dan diresmikan dalam bentuk menurut hukum, oleh atau dihadapan pejabat-pejabat umum, yang berwenang berbuat demikian, dimana akta itu dibuat".

Pendirian PT oleh masing-masing pemegang saham perseroan dilakukan di hadapan Notaris dengan menandatangani akta pendirian PT dan melakukan penyetoran modal ke dalam perseroan yang dibuktikan dengan bukti setor yang akan di upload ke dalam sistem Ditjen AHU. Selanjutnya, akta pendirian PT akan didaftarkan dengan cara memasukkan data PT ke dalam sistem Ditjen AHU online yang dilakukan oleh Notaris, setelah data dimasukan sistem akan mengeluarkan Surat Keputusan persetujuan pendirian PT oleh Menteri Hukum dan Hak Asasi Manusia RI. Perubahan pada PT terjadi setelah 5 tahun kemudian atau sebelum 5 tahun, setelah 5 tahun kemudian PT harus melakukan pengangkatan kembali anggota perseroan, jika sebelum 5 tahun kemungkinan PT melakukan perubahan pada bidang usaha, atau keluar masuknya anggota perseroan. ${ }^{8}$

Akta Fidusia yang dibuat oleh Notaris adalah berdasarkan permintaan Kreditur terhadap terjadinya pinjaman oleh debitur dengan jaminan berupa barang bergerak dan tidak bergerak, atas pinjaman tersebut selain perjanjian kredit yang dikeluarkan oleh kreditur, dibuatkan juga akta fidusia yang akan didaftarkan pada Kementerian Hukum dan Hak Asasi Manusia RI. Pelaksanaan pendaftaran akta fidusia oleh Notaris pada sistem Ditjen AHU adalah dengan memasukkan data akta untuk memperoleh persetujuan bahwa telah didaftarkannya akta fidusia tersebut. ${ }^{9}$

${ }^{8}$ Listyowati, Nunuk. (2015). Tanggung Jawab Hukum Perseroan Terbatas Yang Belum Berstatus Badan Hukum. E-Jurnal Spirit Pro Patria, 1(2). h. 25.

9Santoso, Johari. (2000). Perseroan Terbatas sebagai Institusi Kegiatan Ekonomi yang Demokratis. Jurnal Hukum Ius Quia Iustum, 7(15), 194-203. h. 194. 
Akta Wasiat merupakan akta yang dibuat oleh seseorang semasa hidupnya untuk menyerahkan dan memberikan seluruh harta kekayaannya baik harta kekayaan yang bergerak maupun harta kekayaan yang tidak bergerak, yang dilaksanakan wasiatnya pada saat pemberi wasiat meninggal dunia. Akta wasiat sifatnya boleh dicabut oleh si pemberi wasiat dan boleh melakukan perubahan terhadap isi wasiat sepanjang si pemberi wasiat belum meninggal dunia. Pendaftaran akta wasiat dilakukan oleh Notaris melalui sistem Ditjen AHU online ke dalam Pusat Daftar Wasiat. Pusat Daftar Wasiat berisikan nomor akta, Notaris yang membuat akta, nama si pemberi wasiat telah tercatat di dalamnya.

Seorang Notaris dalam menjalankan jabatannya sebagai pejabat umum selain telah terikat dengan peraturan jabatan, juga terikat pada sumpah jabatan yang diucapkan pada saat pengangkatan sebagai notaris, dimana notaris wajib untuk merahasiakan isi akta dan keterangan yang diperolehnya. ${ }^{10}$ Pada Sistem Adminitsrasi Hukum Umum (AHU) Online lebih memudahkan pengesahan Badan Hukum Perseroan Terbatas dibandingkan dengan sistem-sistem layanan Badan Hukum yang dahulu. AHU online lebih memudahkan pengesahan badan hukum yang dahulu. AHU online menerapkan pelayanan prima dengan mengutamakan pelayanan yang professional, cepat, tepat, efisien, murah dan bebas pungli.

Sistem AHU Online merupakan Sistem Komputerisasi dalam Proses Pengesahan Akta Pendirian Perseroan Terbatas dan Persetujuan Perubahan Anggaran Dasar Perseroan Terbatas. AHU Online merupakan suatu bentuk Pelayanan kepada Masyarakat yang diberikan oleh Departemen Kehakiman Dan Hak Asasi Manusia Republik Indonesia khususnya Direktorat Jenderal Administrasi Hukum Umum dalam Memproses Permohonan Pengesahan Akta Pendirian dan Permohonan Persetujuan dan Penerimaan atau Laporan Perubahan Anggaran Dasar Perseroan Terbatas, yang dilakukan secara online yang dapat diakses oleh seluruh Notaris pada situs http://www.ahu.go.id. ${ }^{11}$

AHU Online merupakan Sistem Komputerisasi sebagai bentuk kerjasama antara penyelenggara jasa layanan internet Departemen Hukum dan Hak Asasi Manusia. Seiap Notaris yang akan mengakses AHU Online haruslah mendaftarkan dirinya ke Kementerian Hukum dan Hak Asasi Manusia. Setelah itu Notaris diberikan suatu User dan Kata Kunci atau password yang terdiri dari Rangkaian Huruf atau Angka yang dapat diubah sesuai dengan keinginan Notaris yang bersangkutan. Selain itu Notaris juga dilengkapi dengan user ID atau nama dari user, biasanya adalah nama dari Notaris itu sendiri, untuk digunakan dalam membuka atau memulai pengaksesan di dalam website AHU yang beralamat di http://www.ahu.go.id. Maka yang dapat melakukan permohonan pengesahan terhadap Akta-akta Notaris hanyalah Notaris itu sendiri, dan tidak dapat lagi Biro Jasa atau orang lain dan bahkan orang dalam perusahaan turut mengurus langsung dalam Proses Pengesahan tersebut.

\footnotetext{
${ }^{10}$ Padry.M, Perlindungan Hukum Penerima Protokol Notaris dan Kewajiban Menyimpan Rahasian Jabatan, Recital Review, Magister Kenotariatan Universitas JambiVol 2 No 1 (2020): Volume2, Nomor 1, Januari 2020.

${ }^{11}$ Permatasari,E. (2017). Peran dan Tanggung Jawab Notaris Terhad ap Pelaksanaan Pendaftaran Badan Hukum Perseroan Terbatas Melalui Sistem Online (Doctoraldissertation, Fakultas Psikologi UNISSULA).
} 
Pendaftaran dengan sistem online adalah pada intinya adalah sama, pendaftaran secara sistem online dibuktikan lebih praktis, dengan beberapa penilaian sebagai berikut :

1. Pendaftaran dengan sistem online lebih praktis karena tidak perlu membawa banyak berkas/file jauh-jauh ke Jakarta dengan resiko hilang atau berkasnya ada yang ketinggalan sehingga harus bolak-balik ke Jakarta. Efisien;

2. Hemat waktu, karena waktu yang dibutuhkan dari pendaftaran sampai mendapatkan SK hanya satu bulan, sedangakan dengan cara manual membutuhkan waktu lama hingga 6 bulan;

3. Tidak perlu jauh-jauh ke Kantor Kemenkuham untuk melakukan pendaftara perseoran terbatas, cukup dilakukan di kantor sendiri sehingga hemat biaya, waktu dan tenaga;

4. Transparant, dengan sistem online pendaftaran dilakukan secara terbuka tidak ada yang disembunyikan karena bila ada kesalahan resiko ditanggung oleh notaris sendiri;

5. Meminimalisir atau menghilangkan praktek kolusi yang pada dasarnya adalah perbuatan atau tindakan yang bertentangan dengan hukum itu sendiri.

Sistem online tidak hanya membuat sangat mudah dan praktis, namun juga lebih cepat, efisien, efektif, ekonomis dan transparan serta dapat meminimalisir atau terhindar dari adanya perbuatan melanggar atau yang bertentangan dengan hukum seperti pungutan liar. Peran notaris sebagai pejabat publik sangat diperlukan dalam mendirikan suatu Perseroan Terbatas sebagai badan usaha yang berbadan hukum, yaitu antara lain:

1. Pembuatan akta pendirian Perseroan Terbatas yang berupa suatu akta autentik;

2. Pengajuan permohonan pengesahan badan hukum Perseroan Terbatas kepada Menteri melalui sistem administrasi badan hukum.

Notaris dalam menjalankan jabatannya selaku pejabat umum selain terikat dengan peraturan jabatan, juga terikat pada sumpah jabatan yang diucapkan pada saat pengangkatan sebagai notaris, dimana notaris wajib untuk merahasiakan isi akta dan keterangan yang diperolehnya. Peran Notaris dalam pendaftaran akta dan pengesahan badan hukum adalah memasukkan data akta, melakukan pengecekan terhadap semua data akta untuk menghindari kesalahan pemasukan data. Kesalahan pada waktu memasukkan data ke dalam sistem adalah hal yang tidak dikehendaki, namun hal tersebut tetap saja bisa terjadi, keadaan tersebut tidaklah terlepas dari peran Notaris. Dengan demikian yang dapat melakukan permohonan pengesahan terhadap akta-akta Notaris hanyalah Notaris itu sendiri, dan tidak dapat lagi biro jasa atau orang lain dan bahkan orang dalam perusahaan turut mengurus langsung dalam proses pengesahan tersebut. Tetapi dalam hal pemesanan nama Perusahaan saat ini sudah dapat dilakukan secara online baik itu oleh masyarakat umum maupun oleh Notaris dengan syarat dan ketentuan yang di tetapkan oleh Direktorat Jenderal Administrasi Hukum Umum (Ditjen AHU). 


\subsection{Tanggung Jawab Notaris Jika Terdapat Masalah Dalam Melakukan Pendaftaran Akta dan Pengesahan Badan Hukum Melalui Layanan Ditjen AHU Online}

Sesuai dengan perkembangan jaman, terlihat bahwa UUPT sudah tidak mampu lagi untuk mencakup dinamika dunia perusahaan, hal ini dapat terlihat Seiring perkembangan jaman, tampaknya UUPT sendiri sudah mulai tidak mampu untuk menampung dinamika dunia usaha, hal ini terlihat dari adanya peraturan-peraturan yang mendukung peraturan tentang usaha-usaha agar tetap melindungi berbagai pihak yang terlibat, sehingga tetaplah pada ketentuan yang seharusnya. hal ini dibuktikan dengan banyaknya peraturan- peraturan pendukung agar dunia usaha tetap pada koridor hukum yang seharusnya. Adanya peraturan-peraturan yang mencakup dunia usaha ini dapat menjadi acuan bagi pelaku usaha dalam proses pendirian Perseroan Terbatas. Dimana notaris memiliki peran dan tanggung jawab dalam legalisasi Perseroan Terbatas, hal ini secara spesifik berhubungan dengan pendirian Perseroan Terbatas baik pengesahan pendirian Perseroan Terbatas secara manual maupun melalui SABH secara online, SABH merupakan Sistem Administrasi Badan Hukum atau SABH (dulu disebut SISMINBAKUM) yakni jenis pelayanan jasa hukum yang diberikan kepada masyarakat dunia usaha dalam proses pengesahan badan hukum PT, pemberian persetujuan perubahan anggaran dasar PT, penerimaan pemberitahuan perubahan anggaran dasar PT dan perubahan data PT, serta pemberitahuan informasi lainnya secara elektronik (melalui jaringan komputer dan internet), yang diselenggarakan oleh Direktorat Jenderal Administrasi Hukum Umum (Ditjen AHU) pada Kementerian Hukum dan Hak Asasi Manusia Republik Indonesia. ${ }^{12}$

Kehadiran peraturan-peraturan dalam bidang usaha menjadi acuan pelaku usaha dalam berkegiatan dan dalam proses pendirian Perseroan Terbatas, dimana notaris memiliki peranan yang cukup dominan dalam legalisasi Perseroan Terbatas secara spesifik berkenaan dengan pendirian Perseroan Terbatas baik pengesahan pendirian Perseroan Terbatas secara manual maupun melalui SABH secara elektronik, serta efektifitas hukumnya dalam masyarakat maupun tanggung jawab yang dipikul oleh notaris dalam melaksanakan perannya dalam proses pengesahan pendirian Perseroan Terbatas. ${ }^{13}$ Sistem Administrasi Badan Hukum (SABH) pada awalnya dikenal dengan sebutan SABH yang merupakan suatu sistem online yang diciptakan oleh Kementerian Hukum dan Hak Asasi Manusia Republik Indonesia, untuk mempercepat proses pengesahan badan hukum Perseroan Terbatas, persetujuan anggaran dasar maupun pelaporan anggaran dan atau data Perseroan Terbatas. Pembentukan Sistem Administrasi Badan Hukum (SABH)merupakan suatu bentuk optimalisasi pelayanan hukum oleh pemerintah kepada masyarakat yang dilakukan dengan menggunakan jejaring teknologi informasi secara online, dimana Kementerian Hukum dan Hak Asasi Manusia Republik Indonesia khususnya Direktorat Jenderal Administrasi Hukum Umum terus bergerak memberikan pelayanan terbaik kepada masyarakat.

Proses pengesahan badan hukum perseroan dalam Sistem Administrasi Badan Hukum melalui online yang dilakukan oleh Notaris dimana Notaris cukup dengan mengakses

${ }^{12}$ Ibid,

13Salim, F. (2020). Peran Notaris Dalam Pengesahan Pendirian Perseroan Terbatas Melalui Sistem Administrasi Badan Hukum (SABH). Recital Review, 2(2), 140-156. 
program aplikasi Sistem Administrasi Badan Hukum secara online. Tanggung jawab notaris terhadap pendirian Perseroan Terbatas dimulai dari adanya ketentuan bahwa pendirian Perseroan Terbatas, sebagai suatu perjanjian, dibuat dan dituangkan dalam suatu akta notariil. Pasal 7 ayat (1) UUPT menetapkan bahwa perseroan terdiri oleh 2 (dua) orang atau lebih dengan akta notaris yang dibuat dalam bahasa Indonesia. Dalam Pasal 1868 ditentukan sebagai berikut :

"Akta otentik adalah akta yang dibuat dan diresmikan dalam bentuk menurut hukum, oleh atau dihadapan pejabat-pejabat umum, yang berwenang berbuat demikian, dimana akta itu dibuat".

Notaris dalam menjalankan jabatannya selaku pejabat umum selain terikat dengan peraturan jabatan, juga terikat pada sumpah jabatan yang diucapkan pada saat pengangkatan sebagai notaris, dimana notaris wajib untuk merahasiakan isi akta dan keterangan yang diperolehnya. ${ }^{14}$

Sebagai seorang notaris memiliki suatu bentuk tanggungjawab untuk dapat mempertanggung jawabkan segala perbuatannya apabila melakukan kesalahan dalam menjalankan tugas dan wewenangnya sebagai seorang pejabat yang memiliki wewenang dalam membuat suatu akta autentik. Adapun tanggung jawab yang diemban oleh Notaris adalah :

a. Tanggung jawab dalam bentuk perdata akan kebenaran materil terhadap akta yang dibuatnya;

b. Tanggung jawab dalam bentuk pidana terhadap akta yang dibuatnya;

c. Tanggung jawab Notaris berdasarkan UUJN terhadap akta yang dibuatnya;

d. Tanggung jawab Notaris berdasarkan kode etik Notaris.

Tanggung jawab Notaris dalam pendaftaran akta dan pengesahan badan hukum dengan sistem online adalah jika terjadi kesalahan dari pihak kantor Notaris maka Notaris akan melakukan perbaikan dengan biaya dari Notaris, namun berkenaan dengan hal tersebut tetap adanya kerjasama dari pihak pemohon mengenai data-data yang diperlukan. Apabila Notaris yang membuat akta tidak sesuai dengan ketentuan UU yang berlaku, maka sanksi dengan tegas akan dijatuhkan oleh Majelis Pengawas Notaris, akibatnya di masa yang akan datang dalam dianalisis pembuatan akta notaris yang tidak sesuai dengan UU di bidang hukum Kenotariatan.

\section{Kesimpulan}

Peran Notaris dalam pendaftaran akta dan pengesahan badan hukum adalah memasukkan data akta, melakukan pengecekan terhadap semua data akta untuk menghindari kesalahan pemasukan data. Kesalahan pada waktu memasukkan data ke dalam sistem adalah hal yang tidak dikehendaki, namun hal tersebut tetap terjadi, keadaan tersebut tidak terlepas dari peran Notaris. Tanggung jawab Notaris dalam pendaftaran akta dan pengesahan badan hukum dengan sistem online adalah jika terjadi kesalahan dari pihak kantor Notaris maka Notaris akan melakukan perbaikan

${ }^{14}$ Aman, A. (2019). Perlindungan Hukum Notaris Dalam Melaksanakan Rahasia Jabatan. Recital Review, 1(2), 59-71. 
dengan biaya dari Notaris, namun berkenaan dengan hal tersebut tetap adanya kerjasama dari pihak pemohon mengenai data-data yang diperlukan.

\section{Daftar Pustaka / Daftar Referensi}

\section{$\underline{\text { Buku }}$}

Adjie, Habib, \& Sjaifurahman, 2011. Aspek Pertanggungjawaban Notaris dalam Pembuatan Akta, CV. Mandar Maju, Bandung

Ibrahin, Johny, 2008, Teori dan Metode Penelitian Hukum Normatif, Banyu Media, Malang.

I Made Pasek Diantha. (2017). Metodelogi Penelitian Hukum Normatif dalam Justifikasi Teori Hukum. Jakarta: Prenada Media Group.

Sjaifurahman \& Habi Adjie. 2011, Aspek Pertanggungjawaban Notaris dalam Pembuatan Akta, CV. Mandar Maju, Bandung.

\section{Jurnal}

Aman, A. (2019). Perlindungan Hukum Notaris Dalam Melaksanakan Rahasia Jabatan. Recital Review, 1(2), 59-71.

Anggraeni, S., \& Marwanto, M. (2020). Kewenangan dan Tanggung Jawab Hukum Pejabat Pembuat Akta Tanah Dalam Pelaksanaan Pendaftaran Hak Tanggungan Secara Elektronik. Acta Comitas : Jurnal Hukum Kenotariatan, 5(2), 261-273.

Budiono, Herlien. (2012). Arah Pengaturan Undang-Undang Nomor 40 Tahun 2007 tentang Perseroan Terbatas dalam Menghadapi Era Global. Jurnal Rechts Vinding: Media Pembinaan Hukum Nasional, 1(2), 187-198.

Erlina Permatasari \& Lathifah Hanim, PERAN DAN TANGGUNG JAWAB NOTARIS TERHADAP PELAKSANAAN PENDAFTARAN BADAN HUKUM PERSEROAN TERBATAS MELALUISISTEM ONLINE, Jurnal Akta, Vol. 4 No. 3 September 2017

Jayanthi Devi, N.M., Wairocana, I.G.N., \& Wiryawan, I.W. (2015). Status Dan Kedudukan Lembaga Perkreditan Desa (LPD) Terkait Pengikatan Jaminan Dengan Berlakunya Undang-Undang Nomor 1 Tahun 2013 Tentang Lembaga Keuangan Mikro. Acta Comitas, 201-212. h. 204.

Listyowati, Nunuk. (2015). Tanggung Jawab Hukum Perseroan Terbatas Yang Belum Berstatus Badan Hukum. E-Jurnal Spirit Pro Patria, 1(2). h. 25. 
Perangin-Angin, E. V. (2019). Analisis Yuridis Atas Gagalnya Pengesahan, Pendaftaran Perseroan Terbatas, Yayasan dan Jaminan Fidusia Melalui Sistem Administrasi Hukum Umum (AHU) Online.

Padry.M, Perlindungan Hukum Penerima Protokol Notaris dan Kewajiban Menyimpan Rahasian Jabatan, Recital Review, Magister Kenotariatan Universitas JambiVol 2 No 1 (2020): Volume 2, Nomor 1, Januari 2020.

Permatasari, E. (2017). Peran dan Tanggung Jawab Notaris Terhadap Pelaksanaan Pendaftaran Badan Hukum Perseroan Terbatas Melalui Sistem Online (Doctoral dissertation, Fakultas Psikologi UNISSULA).

Pratama, I., \& Priyanto, I. (2020). Kepastian Hukum Jumlah Modal Dasar Pendirian Perseroan Terbatas Setelah Berlakunya PP Perubahan Modal Dasar Perseroan Terbatas. Acta Comitas : Jurnal Hukum Kenotariatan, 5(2), 340-350.

Salim, F. (2020). Peran Notaris Dalam Pengesahan Pendirian Perseroan Terbatas Melalui Sistem Administrasi Badan Hukum (SABH). Recital Review, 2(2), 140156.

Santoso, Johari. (2000). Perseroan Terbatas sebagai Institusi Kegiatan Ekonomi yang Demokratis. Jurnal Hukum Ius Quia Iustum, 7(15), 194-203. h. 194.

\section{Peraturan Perundang-Undang}

Kitab Undang-Undang Hukum Perdata (burgerlijk wetboek), dengan tambahan undang-undang pokok agrarian dan undang-undang perkawinan, diterjemahkan oleh R.Subekti dan R. Tjitrosudibio, 2008, Cetakan 39, Pradnya Paramita.

Undang-Undang Negara RI, Undang-Undang No. 2 Th. 2014 tentang perubahan Undang-Undang Negara RI, Undang-Undang No. 30 Th. 2004 tentang Jabatan Notaris (Lembaran Negara RI Th. 2014 No. 3 perubahan atas Lembaran Negara RI Th. 2004 No. 117 Tambahan Lembaran Negara 4432)

Undang-Undang Negara RI, Undang-Undang No. 40 Th. 2007 tentang Perseroan Terbatas (Lembaran Negara RI Th. 2007 No. 106 Tambahan Lembaran Negara RI No. 4756) 